\title{
The Influence of Magnetic Fields Supply and Hygromycin Concentration to the Optimization of Folate Gene Putative Transformant Selection in Rice (cv. Fatmawati)
}

\author{
*Susiyanti \\ Department of Agroecotechnology, \\ Agriculture Faculty \\ University of Sultan Ageng Tirtayasa \\ Indonesia Center of Execelenc for Food \\ Security (I-CEFORY), UNTIRTA \\ (Local Food Innovation) \\ Banten, Indonesia \\ *susiyanti@untirta.ac.id \\ Winda Wati \\ Department of Agroecotechnology, \\ Agriculture Faculty \\ University of Sultan Ageng Tirtayasa \\ Banten, Indonesia
}

\author{
Nurmayulis Nurmayulis \\ Department of Agroecotechnology, \\ Agriculture Faculty \\ University of Sultan Ageng Tirtayasa \\ Indonesia Center of Execelenc for Food \\ Security (I-CEFORY), UNTIRTA \\ (Local Food Innovation) \\ Banten, Indonesia \\ Sulastri Isminingsih \\ Department of Agroecotechnology, \\ Agriculture Faculty \\ University of Sultan Ageng Tirtayasa \\ Banten, Indonesia
}

\author{
Sjaifuddin Sjaifuddin \\ Department of Sciences Education \\ University of Sultan Ageng Tirtayasa \\ Banten, Indonesia
}

\begin{abstract}
The research was aimed to determine the influence of magnetic fields supply and hygromycin concentration on the optimization of folate gene putative transformant selection in rice (cv. Fatmawati). The Genetic transformation of rice used A. tumefaciens strain LBA4404 as a vector that contained plasmid pCambia1300-CGH1 construct through in planta transformation method using scutellum tissue explant. This research was conducted at the Laboratory of Plant Physiology and Biotechnology, Faculty of Agriculture, Sultan Ageng Tirtayasa University, Banten (February to April 2019). This research used a completely randomized design consisting of two factors. The first factor was the supply of a magnetic field, with two levels: without magnet and magnet. The second was the hygromycin concentrations with 4 levels: $25,50,75$, and $100 \mathrm{mg} . \mathrm{L}^{-1}$. The results of the magnetic fields did not affect the transformation efficiency parameters and the percentage of explant deaths. The results of different hygromycin concentrations showed an effect on transformation efficiency parameters and percentage of explants deaths. The concentration of hygromycin $25 \mathrm{mg} . \mathrm{L}^{-1}$ had the highest average of transformation efficiency $100 \%$ based on the number of explants who passed the selection media suspected of being putative transformants and the low percentage of explants deaths $0 \%$. In the lethal test of concentration-50 (LC50) hygromycin, the concentration of hygromycin $75 \mathrm{mg} . \mathrm{L}^{-1}$ caused up to $50 \%$ mortality in rice cv. Fatmawati explants. There had no interaction between the magnetic field supply and the hygromycin concentration on the parameters of transformation efficiency and the percentage of explant deaths.
\end{abstract}

Keywords: Agrobacterium tumefaciens, Hygromycin, Magnetic Field Supply, Oryza sativa L., Transformation

\section{INTRODUCTION}

Rice (Oryza sativa L.) is a very important food crop commodity because it is a staple food for almost half of the world's population, most of which come from developing countries including Indonesia. The need for rice as a staple food continues to increase in line with the increasing population and welfare of the community. Rice holds the most important role among various other food sources in Indonesia in providing food that supports national food security and economic empowerment of farm households. Not only in terms of quantity, but the quality of rice that concerns market interest, taste, aroma, and nutrient content is an important thing that needs to be considered in the future development of rice [1,2]. Therefore, in addition to developing rice plants in terms of quantity such as production and productivity which are considered to be very beneficial to farmers, it is also important to develop quality of rice plants such as nutrients that can benefit consumers.

Folate is a micro nutrient that is needed by the body. Folate has an essential role in facilitating the transfer of onecarbon units in the reactions needed in the synthesis of purines and pyrimidines which are precursors of nucleic acids, for the metabolism of methionine, serine, glycine and histidine and the formation of methylation agents needed for normal metabolism and gene regulation [3]. The daily recommended intake (DRI) for folic acid intake is 400 $\mu \mathrm{g} /$ day for adults, even higher for pregnant women [4].

The problem of micronutrient deficiencies such as folate which is still quite high at this time is an indication of low intake of food sources of vitamins and minerals from the daily diet. Therefore, as an effort to increase folate content in rice which is a staple food consumed every day can be done through folate biofortification. According to [5], folate biofortification in staple plants is one alternative that can be used to increase vitamin intake. Increasing folate content in rice can be done by improving the nature of rice plants by 
utilizing the folate gene (CGH1) which is inserted into the rice plant genome through genetic engineering techniques.

With the development of genetic engineering technology, biofortification of staple crops such as rice can be achieved through gene transformation. The process of gene transformation with intermediaries Agrobacterium tumefaciens is the most effective method, because it provides high transformation efficiency, can be used for large transgenes and tends to result in the integration of a single copy of transgenes in the rice plant genome [6].

One important step that must be passed in the gene transformation system to get GMO plants is the selection. The selection process aims to separate transformant cells and non transformant cells. According to [7], selection of transformed cells was carried out using antibiotics as selection agents. The selection of antibiotics as selection agents is adjusted to the selection marker genes found in the construction of the introduced DNA [8]. Generally, selection is usually done using antibiotics such as hygromycin. In the transformation process, genes that are resistant to hygromycin as a selection marker have been inserted. In recent years, many studies have used magnetic fields to see their effects on the growth and development of a plant. According to [9], the magnetic field stimulates germination and plays an important role in increasing the germination energy. From various studies, it is known that the influence of the magnetic field on plants depends on the intensity and frequency of the given magnetic field, the type of plant that is magnetized, and the length of time of magnetization [10]. Based on the description above, it is necessary to investigate the effect of giving magnetic fields and hygromycin concentrations on optimizing the putative selection of folate gene transformants in rice (Oryza sativa L.) Fatmawati varieties.

This study aims to determine the effect of magnetic field supply and concentration of hygromycin on optimizing the putative selection of folic gene transformants in rice, cv Fatmawati.

\section{MATERIALS AND METHODS}

This research is an experimental research. This research was conducted from February to April 2019 at the Biotechnology Laboratory of the Department of Agroecotechnology, Faculty of Agriculture, Sultan Ageng Tirtayasa University, Serang-Banten.

The type of rice used in this study was local rice cv. Fatmawati. The bacterium used was A tumefaciens strain LBA4404 which carried the pCAMBIA1300 plasmid that had been inserted with the folate gene (CGH1) (Figure 1), gene construction was constructed with the help of Dr. Tri Joko Santoso, SP, M.Sc (ICABIOGRAD, Bogor).

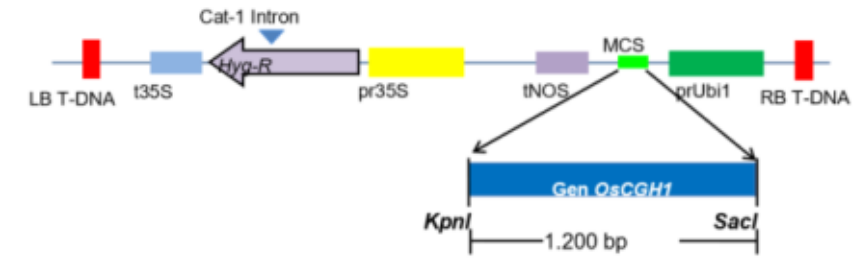

Fig. 1. Diagram of plasmid construction vector expression of pCambia1300-OsCGH1 [11]
This research was carried out by the method of in planta gene transformation. The research design used was a Completely Randomized Design (CRD) prepared factorially. The first factor is without and giving a magnetic field (a) consisting of 2 levels:

\section{a1: Without Magnetic Field}

\section{a2: Magnetic Field}

The second factor is the concentration of hygromycin (b) which consists of 4 levels:

b1: Hygromycin $25 \mathrm{mg} . \mathrm{L}^{-1}$

b2: Hygromycin $50 \mathrm{mg} \cdot \mathrm{L}^{-1}$

b3: Hygromycin $75 \mathrm{mg} . \mathrm{L}^{-1}$

b4: Hygromycin $100 \mathrm{mg} . \mathrm{L}^{-1}$

The data obtained were then analysed using analysis of variance (ANOVA). If the results of the variance show a real to very real effect then further tests are carried out. In this study, further tests were used using the Duncan Multiple Range Test (DMRT) at 5\% level. Whereas, in the lethal parameter concentration-50 (LC50) hygromycin, explants mortality percentage data obtained were analysed using the probit analysis method for hygromycin used. Observational parameters in this study include: transformation efficiency (\%), explant mortality percentage (\%) and lethal concentration -50 (LC50) hygromycin.

\section{Conducting Research on Preparation and Sterilization of Explants}

The explants used were Fatmawati varieties of rice. Rice seeds used as explants are washed and soaked for 20 minutesin a solution of 2 g.l-1 detergent, 2 g/l fungicide, and 2 g.1-1 bactericide. After that, the seeds are rinsed with distilled water. The rice seeds are peeled and taken to LAF (laminar air flow) then sterilized again with $30 \%$ sodium hypochlorite for 15 minutes and rinsed with sterile distilled water 6 times. As a cover of rice seeds soaked in betadine solution as much as 2-3 drops per $100 \mathrm{ml}$ for 5 minutes. Furthermore, the seeds are soaked in sterile water for 2 days at $20 \mathrm{oC}$. Water is replaced once during the soaking process. After 2 days of immersion, the embryo will turn white [12] with modifications).

\section{The Culture of Agrobacterium tumefaciens}

The bacterium A. tumefaciens strain LBA4404 which carries the plasmid pCAMBIA1300 in which the plasmid contains a folate gene (CGH1) is grown on solid LB media + $50 \mathrm{mg} . \mathrm{L}^{-1}$ kanamycin $+50 \mathrm{mg} . \mathrm{L}^{-1}$ hygromycin by means of bacterial suspension is taken then streaked using a loop, the bacteria were incubated at $280 \mathrm{C}$ for 3 days. Bacteria were taken using a spatula and then suspended with sterile aquades $+100 \mu \mathrm{M}$ acetosiringone. Furthermore, bacterial cell density was measured using a spectrophotometer at a wavelength of 600 . The density of bacterial cells used was OD600 $=0,3$ [12] with modifications).

Bacterial inoculation of A. tumefaciens in the Rice Embryonic Apical Meristem

A. tumefaciens is inoculated into the embryo by sticking a sterile needle (1-1,5 mm deep) then immersed in the A. tumefaciens inoculum for \pm 15 minutes. Rice seeds that have 
been inoculated are planted on cocultivation media in the form of tissue + sterile aquades + acetosiringone. The rice seeds in the petri dish are then incubated in a closed room for 4-5 days. After co-cultivation of the sprouts, the rice soaked in a solution containing cefotaxime (300 ppm) for 1 hour [12] with modification).

\section{Hygromycin-resistant germination selection}

Seed that has been germinated was transferred to MS0 selection media without sugar added by $300 \mathrm{mg} . \mathrm{L}^{-1}$ cefotaxime with the treatment of hygromycin antibiotics with concentrations of 25, 50, 75 and $100 \mathrm{mg} . \mathrm{L}^{-1}$. After that, it was incubated for 7 days, with the addition of magnetic field and no magnetic treatment. Rice plantlets that pass the selection media can be used as an indicator of transformative putative rice plants. After leaving the selection stage, transformative putative rice plants are then grown on MS0 media for rooting and subsequently the rice plants can be acclimatized.

\section{RESULTS AND DISCUSSION}

Confirmation of pC1300-CGH1 Construction Confirmation of the presence of the pCAMBIA1300 plasmid carrying the CGH1 gene in the A. tumefaciens strain LBA4404 bacterium is needed to determine whether the A. tumefaciens bacteria used as vectors in the transformation have carried the pCAMBIA1300-CGH1 plasmid construct. Based on the results of direct PCR analysis of single colonies of A.tumefaciens bacteria which were carried out using GCH1- F/R primers and MyTaq kits, direct PCR results indicated that there are single colonies of A. tumefaciens positive bacteria carrying recombinant DNA containing CGH1 gene inserts which are indicated by the formation of DNA bands measuring around $1200 \mathrm{bp}$. Based on these results, A. tumefaciens strain LBA4404 can be used as a transformation vector because it has been shown to contain the pC1300-CGH1 plasmid construct as a target gene for transformation in Fatmawati varieties of rice. A single colony of A. tumefaciens and the results of the direct PCR analysis are presented in Figure 2.

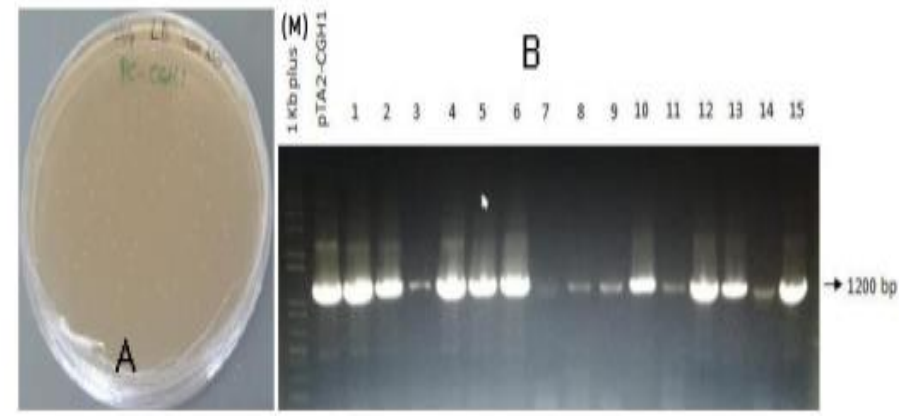

Fig. 2. A single colony of A. tumefaciens was carried out by direct PCR (A). Electrophoresis of agarose gel 1\% DNA from direct PCR results using CGH1 F/R primers produced DNA bands measuring $1200 \mathrm{bp}$ (B); (M) DNA Marker (1 Kb Ladder).

The transformation began by culturing the bacterium A. tumefaciens. The A. tumefaciens bacteria which would be used first was measured its population density at a wavelength of $600 \mathrm{~nm}$. According to [13], bacterial population density is one of the factors that influence the efficiency of transformation, because bacterial population density that is too high can interfere with plant regeneration. Whereas, bacterial population density that is too low can reduce the frequency of T-DNA insertion. In this research, the population density of A. tumefaciens bacteria used with OD (optical density) was 0,3. To provide a bacterial transmission pathway to plants, the infection process of $\mathrm{A}$. tumefaciens needs to be wounded in explants. The wound performed in this research was to insert a sterile needle into the apical meristem of the rice embryo. Other than that, the addition of acetosiringone to $\mathrm{A}$. tumefaciens suspension and cocultivation media can activate the ability to transfer A. tumefaciens genes to plant genomes, considering that rice plants are monocotyledonous plants and do not have acetosiringone compounds. This is in line with the opinion of [14] [15], stating that acetosiringone is a phenolic compound produced by wounded plant cells, which can induce transcription of vir genes on Ti-plasmid A.tumefaciens. Activation of vir genes produces vir proteins which further facilitate the process of gene transfer into plant genomes. In this research, soaking explants in A. tumefaciens suspension was carried out for 15 minutes. Explants that have been infected with A. tumefaciens were grown on co-cultivation media which aim to grow together explants and $\mathrm{A}$. tumefaciens. During the co-cultivation phase there would be integration of the target gene (CGH1 gene) into the rice plant genome. Coultivation time in this research was 4-5 days. A. tumefaciens that have been grown together with explants at the cocultivation stage must be removed so as not to inhibit the growth of explants that are transformed by washing explants using cefotaxime antibiotics, in this study explants were immersed using $300 \mathrm{mg} . \mathrm{L}^{-1}$ cefotaxime. According to [16], cefotaxime is an antibiotic that is commonly used to eliminate bacteria by inhibiting the biosynthesis of bacterial cell walls in the formation of peptidoglycan by deactivating the uncontrolled enzyme transpeptidase and does not interfere with plant growth.

The selection of transformant and non transformant plants was done by growing explants on MS0 selection media containing hygromycin antibiotics as selectable markers. Hygromycin concentration was used in stages, 25, 50,75 and $100 \mathrm{mg} . \mathrm{L}^{-1}$. The explants that were able to escape the selection media can be used as an indicator of transformative putative plants. This is according to research by [17], that explants that have integrated the hpt II gene which is a hygromycin antibiotic resistance gene will be able to survive on the selection media. While non-transformant explants that are not integrated with hygromycin antibiotic resistance genes are browned and die.

\section{Transformation Efficiency (\%)}

Based on the analysis of variance, it shows that the treatment of magnetic fields does not affect the efficiency parameters of the transformation. Meanwhile, the supply of different hygromycin concentrations gave a very real influence on the transformation efficiency parameters. There were no interactions between the two treatments on the transformation efficiency parameters (Table I). 
TABLE I. THE EFFECT OF THE MAGNETIC FIELDS AND DIFFERENT HYGROMYCIN CONCENTRATION SUPPLY ON THE AVERAGE PERCENTAGE OF RICE TRANSFORMATION EFFICIENCY IN FATMAWATI VARIETIES

\begin{tabular}{lccccc}
\hline \multirow{2}{*}{ Treatment } & \multicolumn{5}{c}{ Hygromycin Concentration $\left(\mathrm{mg} . \mathrm{L}^{-1}\right)$} \\
\cline { 2 - 6 } & 25 & 50 & 75 & 100 & Average \\
\hline Without Magnet & 100,00 & 80,00 & 46,67 & 20,00 & 61,67 \\
Magnet & 100,00 & 86,67 & 33,33 & 33,33 & 63,33 \\
Average & $100,00 \mathrm{a}$ & $83,33 \mathrm{a}$ & $40,00 \mathrm{~b}$ & $26,67 \mathrm{~b}$ & 62,50 \\
\hline Notes: The numbers that followed by the same letters in the same row or column show no significant
\end{tabular}

Table I shows the results of the average treatment by giving a magnetic field has a tendency to be higher than the treatment without giving a magnetic field. However, based on analysis of the various the treatments of giving the magnetic field showed no real effect on the efficiency of the transformation. This is presumably because the application of the magnetic field around the explant does not affect the percentage of transformation efficiency but rather affects the physiology of the plant while in the selection media. According to [9], magnetic fields stimulate germination and play an important role in increasing the germination energy.

Table I shows the average results of the transformationefficiency of Fatmawati rice which tends to decrease with increasing hygromycin concentration added to the selection media. This is presumably because the higher the hygromycin concentration the explants do not have resistance to hygromycin antibiotics. Explants that are able to survive or escape hygromycin selection media are indicated by transformative putative explants. According to Mulyaningsih et al. (2010), the presence of hpt genes in transgenic plants can make these plants become resistant to hygromycin antibiotics. This is due to the ability of the gene to produce the enzyme hygromycin phosphotransferase which will detoxify the amino group cyclitol and catalyze the phosphorylation of the hydroxyl group on the hygromycin antibiotic. Hygromycin will then become inactive and be toxic to plants. From the table above, it shows that the concentration of hygromycin $25 \mathrm{mg} . \mathrm{L}^{-1}$ is the concentration that has the highest average transformation efficiency of $100 \%$ (5 live explants out of a total of 5 explants) based on the number of explants that pass through the allegedly putative transformant selection media (Figure 3).
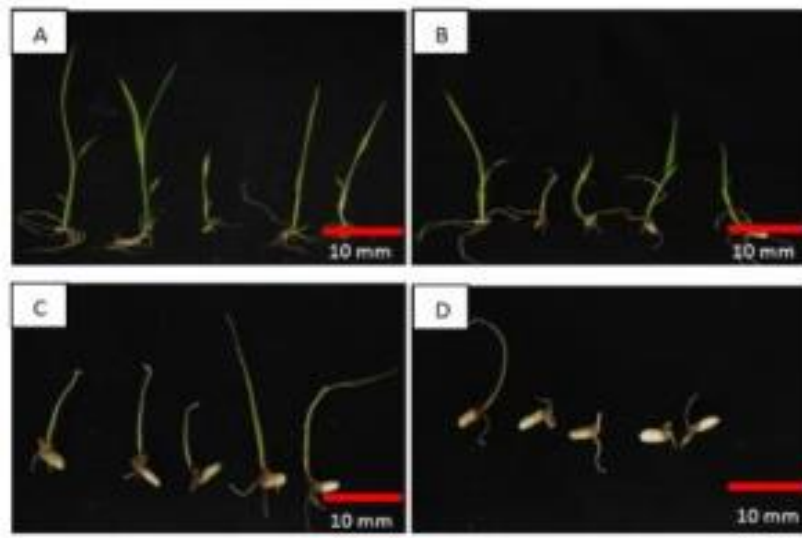

Fig. 3. Visualization of selected rice explants with $25 \mathrm{mg} . \mathrm{L}^{-1}$ hygromycin concentration (A), $50 \mathrm{mg} . \mathrm{L}^{-1}$ hygromycin concentration (B), $75 \mathrm{mg} . \mathrm{L}^{-1}$ hygromycin concentration (C), $100 \mathrm{mg} . \mathrm{L}^{-1}$ hygromycin concentration (D).

\section{Mortality Percentage}

Explants (\%) based on analysis of variance showed that the treatment of magnetic fields did not affect the percentage of explant mortality. Meanwhile, the supply of different hygromycin concentrations gives a very significant effect on the percentage of explant mortality. There was no interaction between the two treatments on the percentage of explant mortality (Table II).

Table II shows that the average percentage of explants mortality in the Fatmawati variety tends to increase with increasing treatment of hygromycin concentration in the selection media. The increase in explant mortality at higher hygromycin concentrations is suspected because the explants experienced poisoning so that they experienced death. According to [18] Cooper (2004), necrotic or cell death occurs because it is related to explant poisoning by the influence of antibiotics. Plant toxicity increases with increasing hygromycin concentration. It results in plants that do not have the hpt gene will experience death in cells or tissue if exposed or grown on a medium that contains hygromycin.

TABLE II. THE EFFECT OF MAGNETIC FIELDS AND DIFFERENT HYGROMYCIN ONCENTRATIONS SUPPLY ON THE AVERAGE PERCENTAGE OF EXPLANT MORTALITY IN FATMAWATI RICE VARIETIES

\begin{tabular}{lccccc}
\hline \multirow{2}{*}{ Treatment } & \multicolumn{5}{c}{ Hygromycin Concentration $\left(\mathrm{mg} . \mathrm{L}^{-1}\right)$} \\
\cline { 2 - 6 } & 25 & 50 & 75 & 100 & Average \\
\hline Without Magnet & 0,00 & 20,00 & 53,33 & 80,00 & 38,33 \\
Magnet & 0,00 & 13,33 & 66,67 & 66,67 & 36,67 \\
Average & $0,00 \mathrm{a}$ & $16,67 \mathrm{a}$ & $60,00 \mathrm{~b}$ & $73,33 \mathrm{~b}$ & 37,50 \\
\hline Note: the numbers that followed by the same letters in the same row or column show no significant \\
difference according to the DMRT test of 5\% level.
\end{tabular}
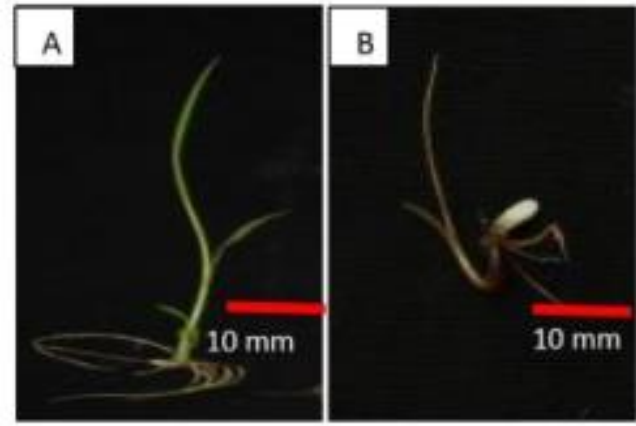

Fig. 4. Visualization of putative transformative Fatmawati rice explants (A) and non transformant explants (B).

TABLE III. DATA FROM HYGROMYCIN LETHAL CONCENTRATION-50 $\left(\mathrm{LC}_{50}\right)$

\begin{tabular}{ccccc}
\hline $\begin{array}{c}\text { Hygromycin } \\
\text { Concentratio } \\
\mathrm{n}\left(\mathrm{mg.L} \mathrm{L}^{-1}\right)\end{array}$ & $\begin{array}{c}\text { Concentration } \\
\log (\mathrm{x})\end{array}$ & $\begin{array}{c}\text { Mortality } \\
\text { rate }(\%)\end{array}$ & $\begin{array}{c}\text { Probit } \\
\text { value }(\mathrm{y})\end{array}$ & $\begin{array}{c}\text { Concentration } \\
\text { of LC50 } \\
\left(\mathrm{mg}_{\mathbf{L}} \mathrm{L}^{-1}\right)\end{array}$ \\
\hline 25 & 1,39 & 0,00 & 0,00 & 75 \\
50 & 1,69 & 16.67 & 4,034 & \\
75 & 1,87 & 60,00 & 5,25 & \\
100 & 2,00 & 73,33 & 5,62 & \\
\hline
\end{tabular}

Table III. shows a hygromycin concentration of $\mathrm{mg} . \mathrm{L}^{-1}$ can cause death up to $50 \%$ in rice explants of the Fatmawati variety. Based on the results of the probit analysis, a linear line equation was obtained, specifically y $9,589 \mathrm{x}-12,98$ and it can be described the relationship curve between the probit value and the hygromycin concentration log, from the 
analysis the Rsq value is 0,944. Based on the regression equation that is logarithmic because it has a value of Rsq = 0,944 , then there is a very strong positive correlation between the hygromycin concentration value to the percentage of explant deaths as evidenced by an $\mathrm{R}$ value close to 1 (Figure 5).

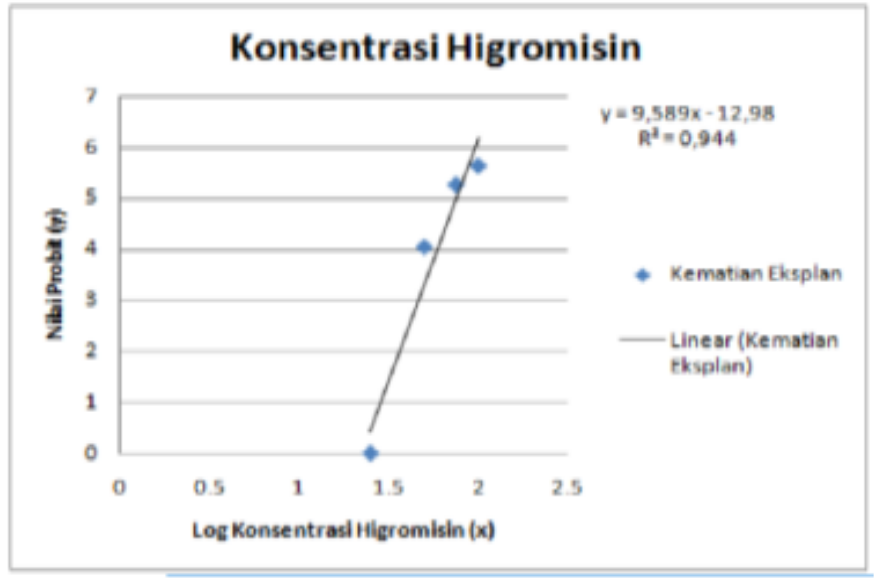

Fig. 5. Linear regression chart for hygromycin concentration

Figure 4 shows the putative explants and non transformant explants. The explants that were suspected to be putative transformants showed good growth in the shoots, leaves and roots, besides explants that appeared fresh and green (Figure 4A). While non-transformant explants showed that the growth of explants is inhibited, although initially explants form shoots and roots, but the explants slowly change color from green to yellowish green, white and subsequently experience browning and then blackening and eventually the explants died (Figure 4B). According to Braun and Bennett (2001), the brown color of sprouts grown in selection media containing hygromycin antibiotics is caused by the inhibition of plant cell metabolism by antibiotics. Inhibition of metabolic processes by the hygromycin antibiotic occurs due to the binding of ribosomes $\mathrm{A}$ in the 30S subunit by antibiotics which cause errors in reading by aminoacyl-tRNA against mRNA in the translation process. In plants, the $30 \mathrm{~S}$ subunit ribosome is in the chloroplast and mitochondrial organelles. In the chloroplasts, the binding of Ribosomes $\mathrm{A}$ in the $30 \mathrm{~S}$ subunit by antibiotics causes damage to chlorophyll and inhibits the formation of amino acids [19].

\section{Lethal Concentration-50 (LC50)}

Hygromycin Lethal concentration-50 or commonly abbreviated as LC50 is a calculation to determine the concentration of extracts or compounds that can kill $50 \%$ of test organisms that can be estimated by graphs and calculations or at a certain observation time [20].

\section{PCR with specific primer}

The transgenic putative was then selected in hygromycin media, and maintained and performed a PCR with the CGH1 gene specific primer. PCR results and the performance of transgenic plants can be seen in Figure 6. Positive rice has a $1200 \mathrm{bp}$ folate gene band, treated and planted in the planting medium.

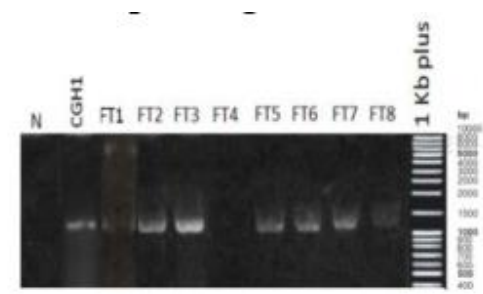

a

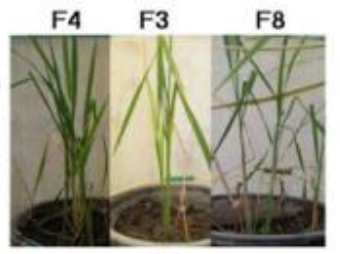

b
Fig. 6. PCR results with specific primers (a); and performance of transgenic putative rice.

Notes: $\mathrm{N}=$ Fatmawati (Non transgenic) FTG1,2,3,4,5,6,7 = Putative folate transgenic of Fatmawati $\mathrm{CGH} 1=$ Agrobacterium tumefaciens which contains a folate gene construct

$1 \mathrm{~kb}$ plus: $=$ Ladder

Based on PCR results, it can be seen that the putative transgenic FT1, FT2, FT3, FT5, FT6, FT7, FT8 have a DNA band size of $1200 \mathrm{bp}$ (same as the control which is Agrobacterium tumefaciens which carries 'construct folate gene'). Putative transgenic samples of FT4 did not have a 1200bp DNA band (the same as the negative control which is Fatmawati rice that was not transformed).

\section{CONCLUSION}

1) Giving a magnetic field showed no effect on the percentage of transformation efficiency and the percentage of explant deaths. Giving a magnetic field showed an average percentage of transformation efficiency higher than without giving a magnet of $63,33 \%$, and showed an average percentage of explant deaths lower by $36,67 \%$.

2) The administration of hygromycin concentration showed the influence of the percentage of transformation efficiency and the percentage of explant deaths. $25 \mathrm{mg} . \mathrm{L}^{-1}$ hygromycin concentration is the best concentration with an averagepercentage of transformation efficiency of $100 \%$ based on the number of explants that pass through the allegedly putative transformant selection media and the lowest average explant mortality rate of $0 \%$. In the lethal test concentration-50 (LC50) hygromycin concentration which can cause death up to $50 \%$ in explants of rice varieties Fatmawati was hygromycin concentration of 75 mg. $\mathrm{L}^{-1}$.

3) There was no interaction between magnetic field supply and hygromycin concentration on the parameters of the transformation efficiency percentage and explant mortality rate.

4) PCR results showed DNA samples of Fatmawati rice FT1, FT2, FT3, FT5, FT6, FT7, FT8 which have a 1200 bp gene encoding DNA band.

\section{REFERENCES}

[1] Praptiwi, Dewi. 2010. Pembentukan dan Seleksi F1 Padi Ciherang Pandan Wangi dan Fatmawati-Mentik Wangi Menggunakan Marka Aromatik. Skripsi. Fakultas Matematika dan Ilmu Pengetahuan Alam, Institut Pertanian Bogor. Bogor.

[2] Susiyanti Susiyanti, Rusmana Rusmana, Yeyen Maryani, Nanang Krisdianto, M. Ana Syahbana. 2020. The Physicochemical Properties Of Several Indonesian Rice Varieties. Biotropia Journal. Vol 27, No1. In press version. http://journal.biotrop.org/index.php/biotropia/article/view/1030 
[3] Scaglione, F., Panzafolta. 2014. Folate, Folic Acid and 5methyltetrahydrofolate are not the same thing. Xenobiotica. Vol. 44 (5): 480-488.

[4] FAO/WHO. 2002. Folate and Folic Acid. in: Human Vitamin and Mineral Requirements. Report of a Joint FAO/WHO Expert Consultation Bangkok, Thailand. FAO, Rome; p 53-63.

[5] Rivera, N.G.R., Carolina, Garc Ia-Salinas., Francisco, J.L., Arag, Ao and Roc, Io Isabel D Iaz De La Garza. 2016. Metabolic Engineering of Folate and Its Precursors in Mexican Common Bean (Phaseolus vulgaris L.). Plant Biotechnology Journal. Vol. 14 (10): 2021-2032.

[6] Hiei Y, Komari T. 2008. Agrobacterium-Mediated Transformation of Rice Using Immature Embryos or Calli Induced from Mature Seed.

[7] Nature Protocols. Vol. 3 (5): 824-834. [7] Arencibia A, Gentinetta E Cuzzoni E, Castiglione S, Kohli A, Vain P, Leech M, Christou P, and Sala F. 1998. Molecular analysis of the genome of transgenic rice (Oryza sativa L.) plants produced via particle bombardment or intact cell electroporation. Mol Breeding. Vol. 4: 99- 109.

[8] Miki, B and Mchugh, S. 2004. Selectable Marker Genes in Transgenic Plants: Applications, Alternatives and Biosafety. Journal of Biotechnology. Vol. 107 (3): 193-232.

[9] Aladjadjiyan, A., Ylieva, T. 2003. Influence of Stationary Magnetic Field on The Early Stages of The Development of Tobacco Seeds (Nicotiana tabacum L.). Journal of Central European Agriculture. Vol. 4 (2): 131-138. Agricultural University, Bulgaria.

[10] Saragih, H., Tobing, J., dan Silaban, O. 2010. Meningkatkan Laju Pertumbuhan Kecambah Kedelai dengan Berbantuan Medan Magnetik Statik. Prosiding Seminar Nasional Fisika. Universitas Advent Indonesia. Bandung.

[11] Susiyanti, Rahmayeti, Nurmayulis, Sulastri, I., Suseno A. 2018. Konstruksi dan Transformasi Gen Folat pada Tanaman Padi Lokal Banten. Laporan Hibah Konsorsium Penelitian Perguruan Tinggi. Universitas Sultan Ageng Tirtayasa. Serang.

[12] Suparthana, I.P., Masahiro Nogawa dan Mineo Kojima. 2014. Identifikasi Transgene pada Tanaman Padi (Oryza sativa var. koshihikari) yang ditransformasi dengan Bantuan Agrobacterium tumefaciens, Menggunakan Metode Tanpa Teknik Kultur Jaringan. Media Ilmiah Teknologi Pangan. Vol. 1 (1): 24-30. Universitas Udayana, Bali.

[13] Mannan, A., T. Noor Syed, and B. Mirza. 2009. Factor Affecting Agrobacterium tumefaciens Mediated Transformation of Artemisia absinthium L. Pakistan Journal of Botany. Vol. 41 (6): 3239-3246. Quaid-i-Azam University, Pakistan.

[14] Purnamaningsih, R., dan D. Sukmadjaja. 2012. Transformasi Genetik Pisang Ambon dengan Gen Kitinase dari Padi. Jurnal AgroBiogen. Vol. 8 (3): 97-104. Bogor

[15] Mulyaningsih, E.S., Aswidinnoor, H., Sopandie, D., Ouwerkerk, P.B and Braun, R., Bennett, D.J. 2001. Antibiotic Resistance in Genetically Modified (GM) Crops. European Federation of Biotechnology Task Group on Public Perceptions of Biotechnology. Briefing Paper No.10: 1-4

[16] Silva, T and Fukai. 2001. The Impact of Carbenicillin, Cefotaxime and Vancomycin on Chrysanthemum and Tobacco TCL Morphogenesis and Agrobacterium Growth. J.Appl.Hort.Vol. 3 (1): 3-12. Kagawa University, Japan

[17] Edia, F.D, Bambang Sugiharto, Esti Utarti. 2014. Transformasi Gen Sosut 1 pada Tanaman Tebu Menggunakan Agrobacterium Tumefaciens Strain GV3101 dan Pangkal Tunas Tebu In Vitro. Berkala Sainstek. Vol. 2 (1): 22-25. Universitas Jember, Jember.

[18] Cooper, J. 2004. Hygromycin: Antibiotic for Gene Transfer. http://www.hygromycin.com. [22 Mei 2019].

[19] Wojtania A, Pulawka J, Gabryszewska E. 2005. Identification and Elimination of Bacterial Contaminants from Pelargonium Tissue Cultures. Journal of Fruit and Ornamental Plant Research. Vol. 13: 101-108. Institute of Pomology and Floriculture Pomologiczna, Poland.

[20] Nurbaeti, E. 2012. Uji Toksisitas Ekstrak Daun Bakau Sonneratia alba Terhadap Artemia. Balai Budidaya Laut Ambon 